\title{
Using Plastic Money (Cards) in Kathmandu Valley: Users' Knowledge, Current Use, Challenges and Way-forward
}

\author{
Niranjan Devkota ${ }^{1 *}$, Bikesh Shakya ${ }^{1}$, Seeprata Parajuli $^{1}$, Udaya Raj Paudel ${ }^{1}$ \\ ${ }^{1}$ Quest International College, Pokhara University, Gwarko, Lalitpur, Nepal \\ Email: niranjandevkota@gmail.com
}

\begin{abstract}
This study aims to understand the users' knowledge about plastic money, its current use, challenges they faced and way-forward. Based on descriptive research design, primary data is used for the purpose as per its suitability. A structured questionnaire has been arranged with the help of KOBO and devised for the information assortments from 404 plastic money users. Results found that people who use plastic money usually work in banks and financial institutions (33.87\%) and are from the nuclear family (62.62\%), with income between $25001-50000$ (56\%). $95.79 \%$ of the respondents know about plastic money, and $86.3 \%$ have plastic money. $88 \%$ of respondents said they feel safe while using plastic money. $40.72 \%$ of respondents have faced challenges and problems while using plastic money. The majority $(79.28 \%$ ) of respondents believed that using the bank's services could be solved. It can be solved by giving training $(34.85 \%)$, quick response to the problem raised by users $(44.32 \%)$, update technology $(34.47 \%)$ and keep a good network in the ATMs (71.79\%) and quick solutions to the user's problems $(75.76 \%)$. This study concludes that hassle-free transactions, a low-interest rate of credit cards, attractive advertisement, and awareness of how plastic money can use help and attract users of plastic money.
\end{abstract}

Keywords: Plastic Money, User Knowledge, Challenges, Way-forward, Kathmandu Valley, Nepal

\section{How to cite:}

Devkota, N., Shakya, B., Parajuli, S., Paudel, U. E. (2021). Using plastic money (cards) in Kathmandu Valley: users' knowledge, current use, challenges and way-forward. International Journal of Business, Management \& Economics, 2(2). 102-117. https://doi.org/10.47747/ijbme.v2i2.303.

\section{Introduction}

Plastic money is the conventional term for a wide range of bank cards, debit cards, credit cards, and so on (Singh, 2017; Raviprolu, 2017). It is a term utilized overwhelmingly about the hard plastic cards we utilize each day instead of banknotes (Negi, 2014). ICMR (2002) stated that the development of plastic money goes back to the 1920s when the first payment card was presented in the USA. Diners Club and American Express propelled the world's first plastic card in the USA in 1950. In the late 1990s, plastic cards turned out to be exceptionally usual, and by 2001, plastic cash had become a primary type of 'ready money. Plastic money is 
an alternate and better method for paying for products and services and is utilized each day instead of genuine monetary certificates (Antony, 2018). As Cohen (2009) and Fung and Halaburda (2016), people worldwide use cards more than cash. There is also an increase in several Debit and Credit card users.

Plastic money is an ongoing use in this $21^{\text {st }}$ century as it is highly advantageous and safe to convey for shopping or voyage. The nations are currently progressively receiving the idea of plastic money. With this, different worries emerge in the customer's brain, some authentic, and some emerge because of the absence of awareness (Jain, 2016). Credit and debit cards' accommodation, security, and prize ideas keep customers utilizing their cards instead of money (Singh, 2017). However, Debit cards permit individuals the accommodation of cards without the stress of piling on unpaid debt. On the off chance, if lose the card or it gets stolen, one can inform the bank and block the card and can save their cash from being stolen (Raviprolu, 2017).

In the Nepalese context, banks seem to be improving in the part of plastic money these days. From the consumer's side, an ever-increasing number of Nepali individuals think it is helpful to convey plastic money in their wallets rather than hard money (Khalti, 2018). Looking into the historical backdrop of banking in Nepal, the first credit card in Nepal was presented by Nabil Bank in 1990, and the Himalayan Bank presented the first ATM in 1995 (Nepal Rastra Bank, 2019). Now all the commercial banks in Nepal issued plastic money. Also, banks and financial institutions have brought up different schemes for the cards. Dhungel et al. (2012) find that people in Kathmandu valley has also started to adopt plastic money more than paper money, and it is expected to increase in future. At present, there are more than 9 ATMs for each one thousand grown-ups in Nepal, having a place with various banks in different locales of the nation(Fintech Trends, 2018).

ICT has progressed in Nepalese commercial banks, and significant headway is in the field of ATM, mobile banking, web banking have a considerable on account of banks reliable endeavours of making customers mindful on different financial facilities (Banstola, 2007). In Nepal, debit and credit cards are readily available once the bank account is opened. After a week in Kathmandu valley, the bank will provide you with the cards and 15 - 30 days outside the valley. Today, most of the cards issued in Nepal are accepted in the ATM of Nepal and India (Republica, 2019). Due to this feature, there is an increase in purchasing goods and services and making payments electronically or through the point of sale (POS). The features of plastic money are that it is readily accepted outside the valley or country, so it is safe as one do not need to carry cash or cheque book. As Shrestha and Tamang (2020), it is safe and helpful to withdraw cash from bank employees. Similarly, Dhungel et al. (2012) state that plastic money will grow in future because of its more straightforward process, security, efficiency and more convenient banking system.

Despite little evidence, a study has not been conducted in the context of Nepal. Still, banks and financial institutions have a paucity of information on why people are not using plastic money. On the other side, many people still do not have a bank account, and most having plastic money do not know how to use the card because of no proper knowledge. It indicates that a communication gap prevails in Nepalese banks to promote and attract customers towards their service and product. In their study, Paudel et al. (2020), Parajuli et al. (2020) 
and Shrestha et al. (2020) find that banking communication plays a vital role to promote and control services provided by the bank among their staff and customers.

Further, Devkota et al. (2021) argued that Nepalese bankers and banking customers are less aware of those banking practices, which makes classless transactions and helps to promote green banking practices. Outside the country, people mostly use cards to make the payment, but in Nepal, still, people do not use them (Hernandez, Jonker, \& Kosse, 2017). Hence, this study aims to identify the user's knowledge about plastic money, its current use, challenges they faced and way-forward.

Other sections of this study include a review of the literature followed by methods used in the study with findings of the study and finally, the study's conclusion.

\section{Literature Review}

\subsection{History of Plastic Money in World}

Plastic Money is a term that is utilized overwhelmingly in reference to the hard plastic cards we utilize each day instead of bank notes (Negi, 2014). They can come in many different forms such as debit cards, credit cards, pre-paid cash cards and store cards. ICMR (2002) states that development of plastic money goes back to the 1920s, when the first payment card was presented in the USA. Diners Club and American Express propelled the world's first plastic card in the USA, in 1950. The first credit card was presented by Diners Club in 1951. In any case, the plastic cards started to be broadly utilized simply after 1970, when the particular gauges for magnetic strip were set. In the late 1990s, plastic cards turned out to be exceptionally normal and by 2001, plastic cash had become a basic type of 'ready money'. To contend in mechanical world, credit and debit cards have gotten progressively effective and in a flash available over numerous mediums. With new advances, for example, portable stages, this shows various open doors for merchants and shoppers the same (Mukaria, 2018). The evolution of plastic cards in presented in the table 1.

Table 1. The Evolution of Plastic Money

\begin{tabular}{|l|l|}
\hline First Phase: 1900-1950's \\
The & $\begin{array}{l}\text { With a background marked by "plastic money", you can't disregard charge } \\
\text { cards. Charge cards laid the basis for debit and credit cards. Organization } \\
\text { gave charge cards can be found as far back as the mid 1900's. These cards } \\
\text { primarily simply stayed with clients faithful to the company (Cashco } \\
\text { Financial Inc, 2016). }\end{array}$ \\
\hline Charg-it & $\begin{array}{l}\text { "Charg-it" was the primary real bank card and was given in 1946. The card } \\
\text { was designed by an investor in Brooklyn, by the name of John Biggins } \\
\text { (Mukaria, 2018). }\end{array}$ \\
\hline $\begin{array}{l}\text { The Diners } \\
\text { Club Card }\end{array}$ & $\begin{array}{l}\text { The idea of the credit card was at first followed up on by Frank Mcnamara. } \\
\text { After dinner with a kindred business partner, Frank wound up short on } \\
\text { money subsequent to overlooking his wallet. What followed was a revelation } \\
\text { that drove him to think about a charge card. This card, later known as the } \\
\text { "Diners Club Card", could be utilized at numerous areas. This clever thought } \\
\text { turned into the principal genuine model of the multipurpose charge card } \\
\text { (Peach, 2018). }\end{array}$ \\
\hline American & \begin{tabular}{l} 
American Express gave their first charge card in 1958. Because of their \\
\hline
\end{tabular}
\end{tabular}




\begin{tabular}{|c|c|}
\hline Express & $\begin{array}{l}\text { worldwide nearness, the Green Charge Card was all around acknowledged. } \\
\text { This turned into the principal globally accessible charge card (Cashco } \\
\text { Financial Inc, 2016). }\end{array}$ \\
\hline $\begin{array}{l}\text { Bank } \\
\text { Americard }\end{array}$ & $\begin{array}{l}\text { In } 1958 \text { Bank of America presented a one of a kind card that could be } \\
\text { utilized to buy anything at taking an interest vendor. As it were, it was an } \\
\text { all-inclusive card so the cardholder didn't require different cards for explicit } \\
\text { goals. This card likewise set industry standards, for example, 25-day } \\
\text { elegance periods, credit limits, and floor limits. The test case program in } \\
1959 \text { at first had } 60,000 \text { clients and was a tremendous achievement. The } \\
\text { program was then turned out state wide in California (Mukaria, 2018). }\end{array}$ \\
\hline Mag Stripe & $\begin{array}{l}\text { Credit and debit cards would not be what they are today without the Mag } \\
\text { Stripe. This pivotal jump in card innovation showed up when the CIA } \\
\text { employed IBM to connect a magnetic stripe to their identity cards. The } \\
\text { innovation was at that point accessible; be that as it may, the fundamental } \\
\text { issue was for all time joining the stripe to the card without wrinkles (Cashco } \\
\text { Financial Inc, 2016). While taking a shot at this issue, Forest Perry got back } \\
\text { home from work to discover his wife other pressing his clothes. At the point } \\
\text { when he referenced the issue about the stripe, Forest's wife requested to see } \\
\text { the prototype card. Utilizing the iron, she figured out how to liquefy the } \\
\text { stripe to the card wrinkle-free. This tackled the whole issue, which permitted } \\
\text { IBM to go into full creation with the Mag Stripe on the entirety of their cards } \\
\text { (Laura, 2019). }\end{array}$ \\
\hline \multicolumn{2}{|c|}{ Second Phase: $1970 \mathrm{~s}-1990 \mathrm{~s}$} \\
\hline VISA & $\begin{array}{l}\text { Initially the Visa card began as the Bank Americard program and was never } \\
\text { expected to go national or worldwide so far as that is concerned. In } 1965 \\
\text { BankAmerica start a permitting program with banks around California. After } \\
\text { enough banks bought in to the program, BankAmerica had the option to } \\
\text { make a joint endeavour bank affiliation. This in the long run turned out on a } \\
\text { worldwide scale and BankAmerica changed the name of their card to VISA } \\
\text { International. They additionally made a local America version named VISA } \\
\text { U.S.A (Cashco Financial Inc, 2016). } \\
\text { Two card frameworks permitted VISA International to be all the more } \\
\text { handily acknowledged across different nations due to having no relationship } \\
\text { with America. The abbreviation VISA represents Visa International Service } \\
\text { Association; BankAmerica felt the name change was proper since VISA } \\
\text { would be in a split second perceived in a wide range of dialects (Laura, } \\
\text { 2019). Their prosperity proceeded and in the long run they joined the Plus } \\
\text { ATM organizes getting much increasingly available to clients around the } \\
\text { globe. These key marking decisions permitted VISA to get one of the most } \\
\text { conspicuous and effective customer marks today (Mukaria, 2018). }\end{array}$ \\
\hline Mastercard & $\begin{array}{l}\text { While the BankAmericard was expanding perspective around California, in } \\
\text { Kentucky their resistance was in like manner expanding strong ground. } \\
\text { Crocker National Bank, Wells Fargo, and Bank of California got together } \\
\text { and pushed the Interbank Card Association (ICA) in 1966. Following three } \\
\text { years, Mastercard changed their logo and turned out with the famous red and } \\
\text { orange covering circle. Regardless, it was not until ten years sometime later }\end{array}$ \\
\hline
\end{tabular}




\begin{tabular}{|c|c|}
\hline & $\begin{array}{l}\text { when Mastercard turned into the Mastercard we know today (Peach, 2018). } \\
\text { The 80s were likewise a progressive decade for MasterCard. They } \\
\text { discharged their crisis card substitution program; they entered the Pacific } \\
\text { Rim, and obtained Cirrus which was the biggest ATM organizes on the } \\
\text { planet. After such a fruitful decade, MasterCard benefited from their } \\
\text { headways and turned into the other key player in the market alongside VISA } \\
\text { (Cashco Financial Inc, 2016). }\end{array}$ \\
\hline Discover Card & $\begin{array}{l}\text { The Discover Card was a progressive card during the 1980s. It explicitly } \\
\text { displayed Sears and Roebuck and Co. clients with another credit card } \\
\text { alternative. This card was the first of its sort to have no yearly expense, } \\
\text { money back, and high credit limits (ICMR, 2002). The main issue was that } \\
\text { since it was related with Sears, different retailers where were prepared to } \\
\text { acknowledge it, as they would support their opposition. In the long run } \\
\text { Discover understood that their image expected to totally isolate from Sears } \\
\text { thus they continued to do as such. Isolating from Sears made Discover } \\
\text { increasingly alluring for different traders to embrace the card. By the mid- } \\
\text { 1990s, Discover turned out to be extraordinarily effective and was a viewed } \\
\text { as a contender of legitimacy to Visa and MasterCard (Peach, 2018). }\end{array}$ \\
\hline \multicolumn{2}{|c|}{ Third Phase: 1990s - Today } \\
\hline Chip and Pin & $\begin{array}{l}\text { One of the more troublesome changes to plastic money accompanied the } \\
\text { reception of chip and pin innovation. This system has gotten a standard with } \\
\text { credit and debit cards and is linked to the magnetic stripe. Chip and Pin } \\
\text { innovation makes cards substantially more secure and individual data is } \\
\text { difficult to take as a result of the encoded chip (Laura, 2019). A cloned chip } \\
\text { can in like manner be speedily obvious as a beguiling card, as each } \\
\text { individual chip is expressly encoded for each individual card. In spite of the } \\
\text { way that this card development has been around since the 1990's, it has } \\
\text { gotten broadly utilized across Canada, and has been compulsory in the } \\
\text { United States from } 2015 \text { (Cashco Financial Inc, 2016). }\end{array}$ \\
\hline Square & $\begin{array}{l}\text { As ready to acknowledge exchanges through a cell phone is a distinct } \\
\text { advantage for organizations. This was generally made conceivable by an } \\
\text { organization called Square. Square permitted a phone to be utilized as a } \\
\text { retail location framework and acknowledge card instalments anyplace } \\
\text { (ICMR, 2002). The gadget basically connects to the earphone jack and has a } \\
\text { card space for the client to swipe their card. Acquainted with the market } \\
\text { with a } 2.75 \% \text { level rate expense, portable card per users have certainly a } \\
\text { noteworthy commitment to plastic cash. Square has opened the entryway for } \\
\text { some private companies over the world that would now be able to offer their } \\
\text { customers more approaches to pay (Mukaria, 2018). }\end{array}$ \\
\hline YesCard & $\begin{array}{l}\text { The YesCard is another method for getting to online advances and getting } \\
\text { cash in a flash. The old methods for taking advances as a cheque or cash, } \\
\text { sitting tight days for preparing and afterward setting aside the effort to } \\
\text { deposit the cash are no more! The Yes Card permits you to access and utilize } \\
\text { your credits whenever wherever and quicker than anyplace else (Laura, } \\
\text { 2019). }\end{array}$ \\
\hline
\end{tabular}




\subsection{History of Plastic Money in Nepal}

The historical backdrop of banking in Nepal goes back to the year 1937 AD with the foundation of Nepal Bank Limited as the principal business bank in Nepal. It was built up as a semi-government manage an account with metallic coins worth NRs 10 million as the approved capital. Banknotes in Nepal weren't presented up until the mid-1940s (Khalti, 2018). It was in the year 1945 that the soonest banknotes were given by the treasury "Sadar Muluki Khana". These notes were marked by a "Khajanchi", the leader of the treasury who additionally was a high Hindu Priest (Fintech Trends, 2018). Later in the year 1955, Nepal Rastra Bank Act was defined for a better banking system and Nepal Rastra Bank was set up in 1956 as the Central Bank of Nepal likewise. After this date, the banknotes were given by the Central Bank with the marks of the governors of the organization (Nepal Rastra Bank, 2019). Till the 1980s, the banking sector was completely possessed by the government, with Agriculture Development Bank, Rastriya Banijya Bank, NBL and NRB being the mainstays of financial organization in Nepal. 1984 saw the beginning of the private banking industry with the foundation of Nabil Bank and the introduction of outside banks, for example, the Nepal Arab Bank, Nepal Indosuez Bank and Nepal Grindlays (Fintech Trends, 2018). The financial segment in Nepal has confronted numerous obstacles and hindrances. It has experienced different political clashes and unsteadiness. However, today, it stands more changed and modernized. There are different kinds of banks working in the cutting edge banking framework in Nepal.

The development in the banking sector has radically changed the paying propensities for individuals. It wasn't quite a while in the past when individuals just managed hard money. Lining in banks to pull back the littlest measure of cash likewise wasn't abnormal. Be that as it may, today, an ever increasing number of Nepali individuals think that it's helpful to convey plastic money in their wallets rather than hard money (Khalti, 2018). On the off chance that we think over into the historical backdrop of banking in Nepal, the first credit card in Nepal was presented by Nabil Bank in 1990, and the first ATM was presented by the Himalayan Bank in 1995 (Nepal Rastra Bank, 2019). In any case, it couldn't bring a quick jump into individuals' conduct. In spite of the fact that ATM was introduced, it wasn't in a sufficient sum at that point. Be that as it may, presently, there are in excess of 9 ATMs for each one thousand grown-ups in Nepal, having a place with various banks in different locales of the nation (Fintech Trends, 2018). Nepal Rastra Bank (2020) as on mid-December, there are 7,669,827 debit cards in which 7,379,610 is of grade ' $A$ ' banks, 251,848 is of grade ' $\mathrm{B}$ ' banks and 38,369 is of grade ' $\mathrm{C}$ ' banks. There are 168,682 credit cards issued till now by grade 'A' banks and other doesn't have it as per Nepal Rastra Bank rule. There are total of 4191 ATM booth in which 3831 is of grade ' $A$ ' bank, 309 is of grade ' $B$ ' banks and 51 is of grade ' $\mathrm{C}$ ' bank in Nepal.

\section{Research Methods}

\subsection{Study Area, Population, Sample Selection and Data}

Nepal Rastra Bank listed that among 27 commercial banks of the country, all of them have their headquarters in Kathmandu (Nepal Rastra Bank, 2019). Relevant data and a significant 
number of users' can be held from different banks and its system in the network, which will be invaluable for the study. The researcher's motivation for choosing the territory is to obtain the data on how correspondence is rehearsed in the bank and saw by users' as the banks inside Kathmandu valley is by all accounts adjusting with the modernized technology and rehearsing it. Thus, Kathmandu Valley is chosen for the study (Figure 1). Kathmandu Valley includes three districts, Kathmandu, Lalitpur, and Bhaktapur, which spread a zone of 899 square kilometres, while the zone of the Valley overall is 665 square kilometres (Shrestha et al., 2020; Tandukar et al., 2021). The valley encases the whole territory of the Bhaktapur region, $85 \%$ of Kathmandu district and half of Lalitpur district. Kathmandu Valley lies between the latitudes $27^{\circ} 32^{\prime} 13^{\prime \prime}$ and $27^{\circ} 49^{\prime} 10^{\prime \prime}$ north and longitudes $85^{\circ} 11^{\prime} 31^{\prime \prime}$ and $85^{\circ} 31^{\prime}$ $38^{\prime \prime}$ east and is situated at a mean rise of around 1,300 meters (4,265 feet) above ocean level (Pant \& Dongol, 2009; Adhikari et al., 2021).

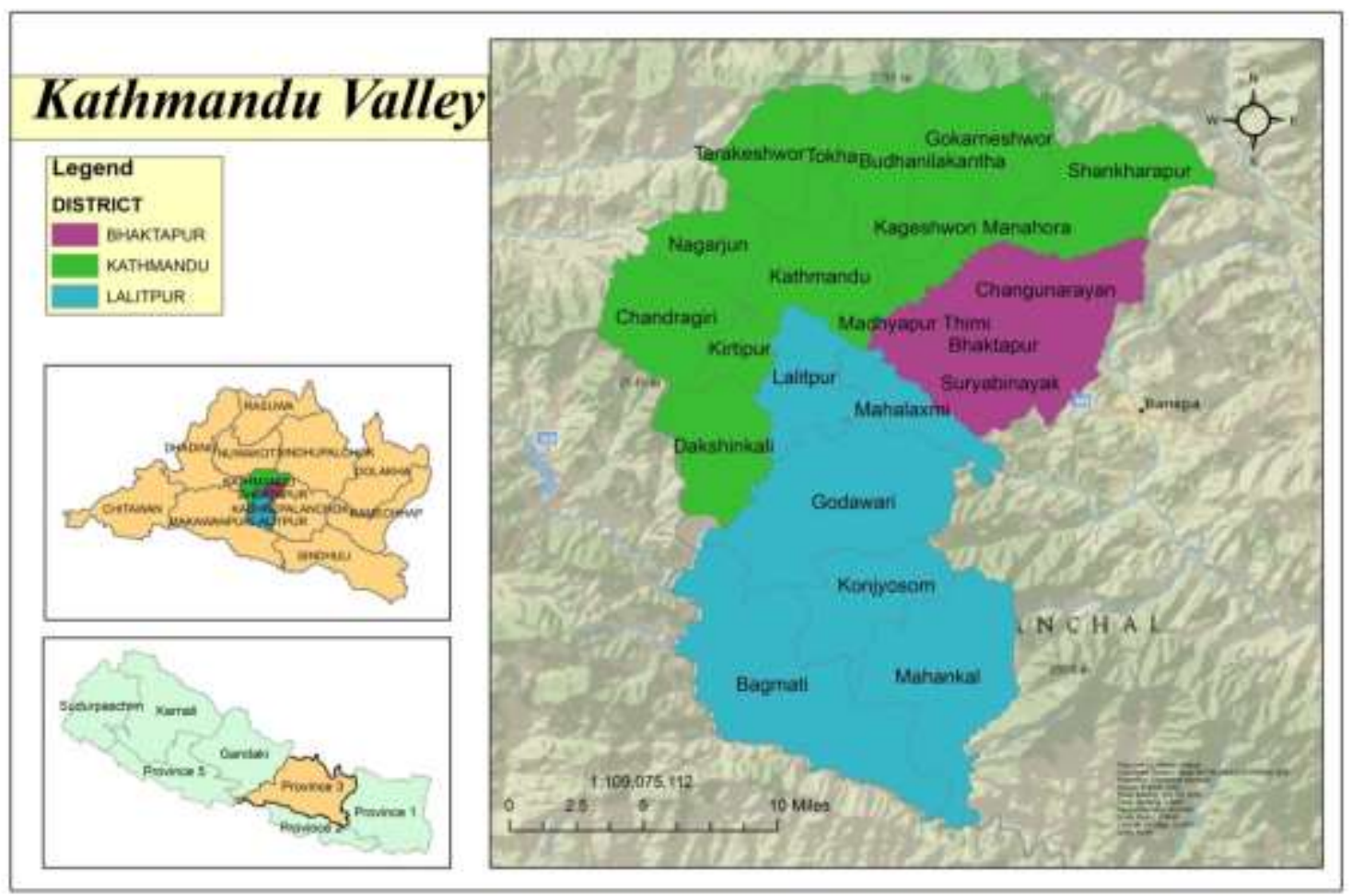

Figure 1. Study Area

Source: Made with ArcGIS 10.2

This study is based on descriptive research design and primary data. Primary data are collected with the help of a questionnaire. Currently, there are 6,819,602 users of debit cards combining users' of all A, B, C grade banks, and 137,656 users' of credit cards as of the end of mid-December 2019 (Nepal Rastra Bank, 2019). So, all banking customers inside Kathmandu valley are regarded as the population for this study.

This study follows a convenient sampling technique, as there is no proper record of the customers and their time to come and go to the banks and use plastic money. The sample size for the study is determined with the help of Singh \& Masuku (2014), Paudel et al. (2020). The formula used to derive the sample size is $n=z^{2} p q / e^{2}$ (Singh \& Masuku, 2014). Where, 
$n_{o}=$ sample size required for study, Standard tabulated value for $95 \%$ confidence level $(\mathrm{z})=$ $1.96, \mathrm{p}=$ Prevalence of customer satisfaction on plastic money $50 \%=0.5$, So, $\mathrm{p}=0.5, \mathrm{q}=1-\mathrm{p}$, $=0.5$, allowable error that can be tolerated $(\mathrm{e})=5 \%$. Total population for the study $\mathrm{n}_{0}=$ $\mathrm{z}^{2} \mathrm{pq} / \mathrm{e}^{2}=(1.96)^{2} \times 0.5 \times 0.5 /(0.05)^{2}=384.16$. We also undertake $5 \%$ non-response error i.e. $384.16 * 5 / 100=19.20$. Thus, the sample size taken for the study was $(384.16+19.20)=$ $403.36(\approx 403)$. Based on the sample calculator, the sample size taken for the study is 404 . A structured questionnaire has been arranged with the help of KOBO and devised for the information assortments, which are taken from 404 plastic money users. Once collected, data is processed and analyzed using Ms Excel.

\section{Results and Discussion}

\subsection{Socio-Demographic Characteristics}

Socio-demographic characteristics such as sex, age, education level, family type, profession and income of 404 respondents were interviewed in three districts, i.e. Kathmandu, Lalitpur, Bhaktapur, to identify the use of plastic money. For this study, $57 \%$ of respondents were male, and $43 \%$ were female, which depicted that most plastic money users are male than female (Table 2). Lanjewar (2015), in his study, found that $52.66 \%$ are male respondents and $47.34 \%$ respondents are female respondents, which is similar to our study. Devlin et al. (2007) found that $53.3 \%$ are male, and the remaining is female in his study. This demonstrates that males utilize and embrace more plastic cards than females. This is because females are, as yet by and large, monetarily reliant on their families.

Table 2. Socio-Demographic Characteristics

\begin{tabular}{|l|c|c|}
\hline S. N. & Number & Percentage \\
\hline Gender & & \\
Male & 231 & $57 \%$ \\
Female & 173 & $43 \%$ \\
\hline Age & & \\
$16-20$ & 25 & $6.19 \%$ \\
$21-30$ & 235 & $58.17 \%$ \\
$31-40$ & 123 & $30.45 \%$ \\
Above 40 & 21 & $5.2 \%$ \\
\hline Level of Education & 7 & \\
Below SEE/SLC & 107 & $2.23 \%$ \\
SEE/SLC & 190 & $5.2 \%$ \\
10+2 & 70 & $17.33 \%$ \\
Bachelor & 21 & $47.03 \%$ \\
Masters & 3 & $26.49 \%$ \\
Above Masters & 2 & $1.73 \%$ \\
\hline Income & 57 & $1 \%$ \\
Below 10000 & 176 & $18 \%$ \\
10001-25000 & 57 & $56 \%$ \\
25001-50000 & 21 & $18 \%$ \\
50001-100000 & & $7 \%$ \\
Above 100000 & 253 & \\
\hline Family type & 54 & $80.94 \%$ \\
Nuclear & & $17.57 \%$ \\
Joint & 12 & $3.83 \%$ \\
\hline Profession & & \\
Agriculture & & \\
\hline
\end{tabular}




\begin{tabular}{|l|c|c|}
\hline Banking and Financial Institution & 106 & $33.87 \%$ \\
Industry Sector & 11 & $3.51 \%$ \\
Own Business & 32 & $10.22 \%$ \\
Teaching & 7 & $2.24 \%$ \\
Government Employees & 26 & $8.31 \%$ \\
Health Professional & 20 & $6.39 \%$ \\
Service & 71 & $22.68 \%$ \\
Others & 28 & $8.95 \%$ \\
\hline
\end{tabular}

Qureshi et al. (2018) has found that most between 30-36 use plastic money in Pakistan. Also, Raviprolu (2017) has concluded that age between 26-35 uses the card more. Our study has found that most plastic money users (58.17\%) are ages 21-30. This study shows that most of the respondents are educated, and the majority (47.03\%) are bachelor degree holders. Bansal (2018) mentioned that under-graduates use plastic money more, which is similar to the result of our study. Bansal (2018) also found that most plastic money users were students, but our study shows that most users work in banks and Financial Institutions. Even the result shows that most of the people who use plastic money are from a nuclear families. $56 \%$ of the respondents who uses plastic money have income between 25001- 50000. Two-third of respondents have an income of more than Rs. 25000 so they find it easier to use plastic money rather than using paper money. Jain (2016) has found that $59 \%$ of the respondents have a monthly income between 21000 - 50000 uses plastic money to a greater extent which shows a similar result with our study. The study further shows that people who use plastic money usually work in banks and financial institutions (33.87\%) and are from nuclear families $(62.62 \%)$.

\subsection{Knowledge about Plastic Money by the Users}

This section deals with knowledge about debit and credit cards. This part portrayed the general understanding of plastic money that includes users bank account related information, their knowledge about plastic money, type and use of plastic money that users hold and other security-related information. Results from the study found that $93.07 \%$ of the respondents had a bank account. It also revealed that a single customer had more than one bank account. $77.39 \%$ of respondents who had bank account had 2-5 bank accounts, and 34 respondents had six and above bank accounts. This shows that the majority of the respondents who have two to five bank accounts are aware of the importance of the bank account. As Sharma et al. (2015), they use the bank account for the transaction of cash as they feel secure and easy.

In terms of knowledge about plastic money, $95.79 \%$ of the respondent knows about the plastic money. Two hundred forty-eight respondents learned about plastic money from the bank, and 236 respondents also knew about plastic money from formal education. There was also the response that the respondents know about the plastic money from a newspaper, pamphlet and hoarding board, and television. It shows there is available information about plastic money. In their study, Ismail et al. (2014) found that most of the respondents get knowledge about ATM cards from the bank.

Table 3. Type of Plastic Money

\begin{tabular}{|l|c|c|c|c|c|c|}
\hline \multirow{2}{*}{ Type of card } & \multicolumn{4}{|c|}{ Number of cards } & & \\
\cline { 2 - 7 } & 1 & $2-3$ & $4-5$ & $\begin{array}{c}\text { Six and } \\
\text { above }\end{array}$ & Total & Total (Percentage) \\
\hline Credit Card & 4 & 3 & 0 & 0 & 7 & 2.1 \\
\hline
\end{tabular}




\begin{tabular}{|l|c|c|c|c|c|c|}
\hline Debit Card & 50 & 151 & 52 & 2 & 255 & 76.35 \\
\hline Both & 0 & 23 & 39 & 10 & 72 & 21.55 \\
\hline Total & 54 & 177 & 91 & 12 & 334 & \\
\hline Total (Percentage) & 16.16 & 53 & 27.25 & 3.64 & & 100 \\
\hline
\end{tabular}

Source: Survey data

$86.3 \%$ out of 404 of the respondents had a debit card or credit card or had both types of card. $53 \%$ of the respondents have $2-3$ cards, where $3.64 \%$ of respondents have a six and above a number of the card. Most respondents have a debit card, i.e. $76.35 \%, 21.55 \%$ of respondents have both the debit card and credit card. Table 3 shows that the majority of the respondents have a debit card. People are still unaware of credit cards, or they think they spend more if they use them. Some of them also said they do not want to pay interest. People use debit cards more than credit cards as credit cards can cause financial trouble to them. Antony (2018) has found out that credit users are more than debit card users, but in our study, we can see debit card users are more than a credit cards.

Table 4 illustrates the use of plastic money by the users in a month. The result shows that the highest number of respondents, i.e. $62.57 \%$, uses the card six to ten times in a month where out of $62.57 \%$ respondents, $61.07 \%$ respondents use plastic money for an amount between $10001-50000$ in a month. Only $0.6 \%$ of respondent uses the card for more than 21 times in a month. $96.11 \%$ of the respondents use the card for withdrawing money from ATMs, 59.28 $\%$ of respondents use the card for online purchases on eCommerce. Respondents also use cards to buy personal items and clothes, use them in restaurants, in the entertainment sector, and buy groceries. $83.49 \%$ of respondents use plastic money because of the instant transaction, while $61.32 \%$ of respondents use plastic money because of its ease of use as per the study conducted in India (Sharma et al., 2015).

Table 4. Use of Plastic Money

\begin{tabular}{|c|c|c|c|c|c|c|c|}
\hline & \multicolumn{5}{|c|}{ Transaction Amount } & & \\
\hline Time Used Card & $\begin{array}{l}500- \\
5000\end{array}$ & $\begin{array}{l}5001- \\
10000\end{array}$ & $\begin{array}{c}10001- \\
50000\end{array}$ & $\begin{array}{l}50001- \\
100000\end{array}$ & $\begin{array}{c}100001 \\
\text { and } \\
\text { Above }\end{array}$ & Total & Total (Percentage) \\
\hline $1-5$ & 30 & 34 & 29 & 0 & 0 & 93 & 27.85 \\
\hline $6-10$ & 2 & 16 & 164 & 24 & 3 & 209 & 62.57 \\
\hline $11-20$ & 0 & 0 & 11 & 14 & 5 & 30 & 8.98 \\
\hline 21 and More & 0 & 0 & 0 & 2 & 0 & 2 & 0.6 \\
\hline Total & 32 & 50 & 204 & 40 & 8 & 334 & \\
\hline $\begin{array}{l}\text { Total } \\
\text { (Percentage) }\end{array}$ & 9.58 & 14.97 & 61.07 & 11.97 & 2.41 & & 100 \\
\hline
\end{tabular}

Source: Survey data

Similarly, $91.62 \%$ of the respondents deposit or pay the amount for the card by themselves. $9.58 \%$ respondent has said that their guardians or parents deposit for the plastic money they use. Most of the respondents deposit in the bank account by themselves. However, some respondents are spouse, partner, and parents pay for the plastic money. This shows that the majority of respondents pays for themselves (Worthington, 1996). Also, it is observed from the analysis that $60 \%$ of respondents have said both English and Nepali language is available in the ATM they use. $39 \%$ of respondents have said only the English language is available in the ATM they use. Language plays a vital role in understanding the message (Abuarqoub, 
2019). Most of the respondents said it is available in both English and Nepali languages in ATMs they use. $25 \%$ of respondents said it is available in the English language only. The study conducted in Ghana has found that the ATM uses the primary language spoken in the country (Larkotey, Danso Ansong, Damoah, \& Laryea, 2012).

It is also found that $74.55 \%$ of respondents have said they do not use other banks ATMs, whereas $25.45 \%$ of respondents have said they use other bank ATMs. Out of $25.45 \%$ respondents, 55.29\% respondents have said that they use the card 1-2 times a month in another bank ATMs. $4.71 \%$ of respondents have said that they use for five times or more in another bank ATMs. In Finland, the consumer's financial losses vary between 140 and 22540 Euros, and the users do not use other banks ATMs (Koivunen \& Tuorila, 2015). Figure 2 shows that most of the users do not use other bank ATMs. They said they need to pay an extra amount if they use it. Some of the respondents said they use other banks ATMs also to draw money. This study finds that $88 \%$ of respondents had said they feel safe while using plastic money, whereas $12 \%$ have said they do not feel safe while using the plastic money

The majority of the users think they feel safe while using Plastic Money. They feel secured while using the card. Most of the respondents said they carry plastic money only because of safety. Lower and middle-income families considered the credit facility a cheerful bit of leeway, while high league salary families discovered security and accommodation to be certain favourable circumstances (Negi, 2014). The analysis found that 34 respondents who do not use plastic money had said that they never needed to use the card, whereas 25 respondents had said they are not financially disciplined. They have also said that they do not use it because they do not know how to use it.

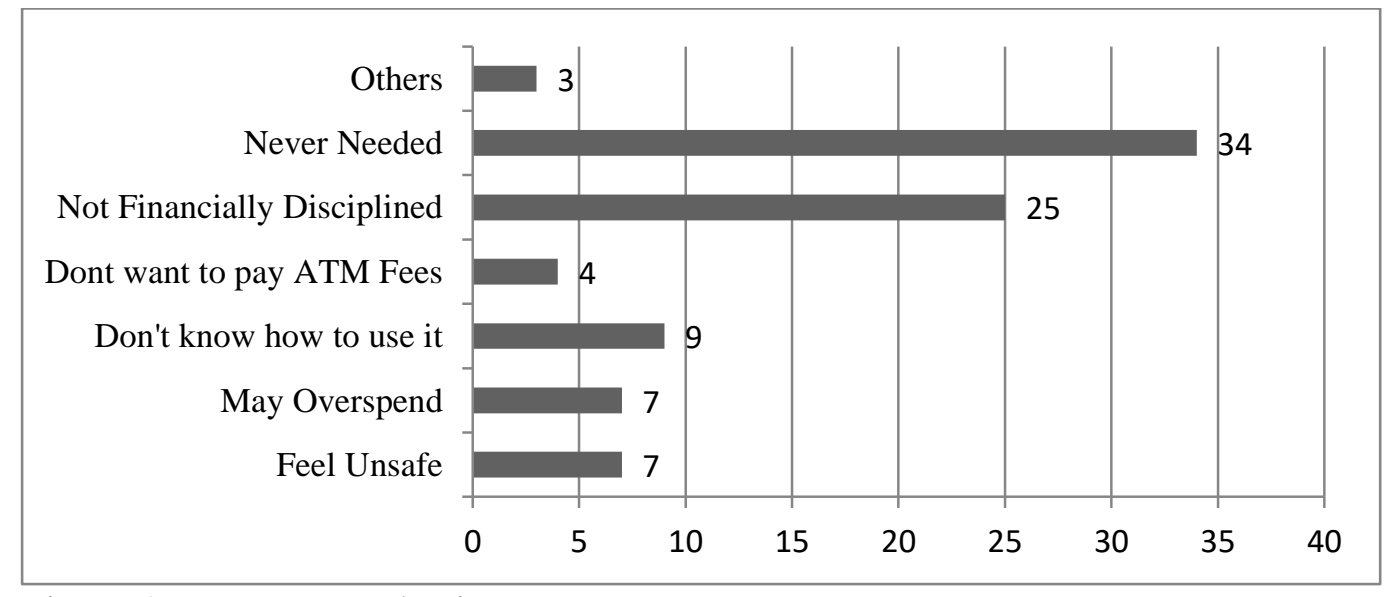

Figure 2. Do not use Plastic Money

Source: Survey Data

The bar diagram shows the reasons why users do not use plastic money. Respondents had said they did not need plastic money and they are not financially disciplined. Some of them also said they do not want to pay ATM fees, do not know how to use it, may overspend and feel unsafe to use the card. $98.11 \%$ of respondents do not use plastic money because of fear of losing a card, whereas $12.26 \%$ do not want to pay ATM fees as per the study results conducted in India (Sharma et al., 2015). 


\subsection{Challenges and Problems faced during use of plastic money}

In Nepal, the traditional payment system is still dominant. Therefore, there are numerous challenges in the use of plastic money. In their study, Hernandez et al. (2017) concluded that $13 \%$ of respondents face problems, whereas $47 \%$ of respondents said they had not faced any problems. The study revealed that $40.72 \%$ of respondents had faced challenges and problems while using plastic money and $48.65 \%$ of respondents perceive that they can get into financial trouble using plastic money. Likewise, $9.84 \%$ of plastic money users feel that problems can be solved easily without contacting banks, whereas $4.15 \%$ stated that problems are not solved even after contacting banks.

For considering the problems being faced by customers while using plastic money, banks may start to consider having a direct telephone line to the cards division appended to the ATMs. This would help clients report their difficulties promptly without strolling or travelling to the bank for their issues (Larkotey et al., 2012). Another challenge is the improper functioning of the POS machine, which deducts the amount even in the case of transaction failure. ATMs not working correctly and timely, stocking of cards into machine, deducting amounts from the account, and not being able to get money from ATM are unnecessary problems customers face for using plastic money. Therefore, banks need to consider all the challenges and problems while using plastic money and provide a secure and comfortable environment for encouraging customers to use plastic money. The bank must work precisely to solve the problems so that their relationship with the customer does not end up in negative relation. The bank should minimize the insecurity that users felt by giving them accurate information and proper training about being safe from cybercrimes.

Eucheuma (2004) found that customers have never faced any loss because of the use of plastic money. On the contrary, to his findings, our study revealed that in Nepal, $81.82 \%$ of plastic money users faced loss between the amounts of Rs. $500-5000$ and $15.15 \%$ had said that they had to face a loss of Rs.5001- 10000. Further, there are various other reasons why people do not use plastic money. Some of the primary reasons for people being reluctant to use plastic money are fears shop charges more $(14.71 \%)$ while paying with plastic money, fees charged by the bank is high (59.46\%), fear of hackers $(28.23 \%)$, commission of the bank they charged are high $(77.48 \%)$. Lack of education prevented the customer from using the ATM (Larkotey et al., 2012). Because over spending, immediate spending of income and no long-term planning and investment have prevented using plastic money (Hernandez et al., 2017).

Table 5: Problem faced while using Plastic Money

\begin{tabular}{|l|c|c|c|c|}
\hline Problem faced while using Plastic Money & Yes & Yes (\%) & No & No (\%) \\
\hline Do not know how to use Card & 50 & 15.02 & 283 & 84.98 \\
\hline Amount debited but cash not Dispensed & 107 & 32.13 & 226 & 67.87 \\
\hline Debited amount more than Once & 93 & 27.93 & 240 & 72.07 \\
\hline Less Cash Dispensed & 81 & 24.32 & 252 & 75.68 \\
\hline Debited without the use of Card & 65 & 19.52 & 268 & 80.48 \\
\hline Theft / Loss & 123 & 36.94 & 210 & 63.06 \\
\hline Forgot Pin & 197 & 59.16 & 136 & 40.84 \\
\hline Card was Stocked & 103 & 30.93 & 230 & 69.07 \\
\hline Problem while Contacting Customer Service Department & 95 & 28.53 & 238 & 71.47 \\
\hline Network Problem & 122 & 36.64 & 211 & 63.36 \\
\hline
\end{tabular}




\begin{tabular}{|l|c|c|c|c|} 
Trouble in Finding ATM & 104 & 31.23 & 229 & 68.77 \\
\hline NRB Policy & 108 & 32.43 & 225 & 67.57 \\
\hline Card Not received in time & 133 & 39.94 & 200 & 60.06 \\
\hline Hack by Hacker & 8 & 2.4 & 325 & 97.6 \\
\hline Others & 52 & 15.62 & 281 & 84.38 \\
\hline
\end{tabular}

The study also revealed that $15.02 \%$ of respondents do not know how to use a debit card (Table 5). 32.13\% faced the amount debited from their account, but cash was not dispensed. $27.93 \%$ of user's amount was debited more than once from their account, and $24.32 \%$ of user's cash was dispensed less than the actual amount. Also, $19.52 \%$ of the user's account was debited without using the card, whereas $36.94 \%$ lost their card.

Hernandez et al. (2017) has concluded that most of the respondents have faced financial problems because of plastic money.59.16 \% of users forgot the PIN of the card. $30.93 \%$ user's card was stuck in ATMs. $28.53 \%$ of users could not use ATMs because of network problems. $31.23 \%$ revealed that it was hard to find ATMs of the bank they have an account with. Because of the change in the policy of Nepal Rastra Bank on magnetic Strip card to the chip card, $32.43 \%$ were not able to use the card. It also shows a lack of information dissemination by banks. $39.94 \%$ had a problem because they did not receive the card on time. $2.4 \%$ user's account was hacked, and $15.62 \%$ faced several other problems while using ATMs.

\subsection{Managerial Suggestion}

The majority (79.28\%) of respondents believed that using the bank's services could be solved. $34.85 \%$ said it could be solved by training to use the card for the first time to the user. 44.32 $\%$ said that banks should have a quick response to the problem which users raise. $34.47 \%$ said the bank should use updated technologies, and $71.59 \%$ said that the bank should keep a good network in the ATMs. Further, $75.76 \%$ said the bank should give quick solutions to the user's problems. However, $20.72 \%$ of respondents said the problems are not manageable because of the improper management of the bank.

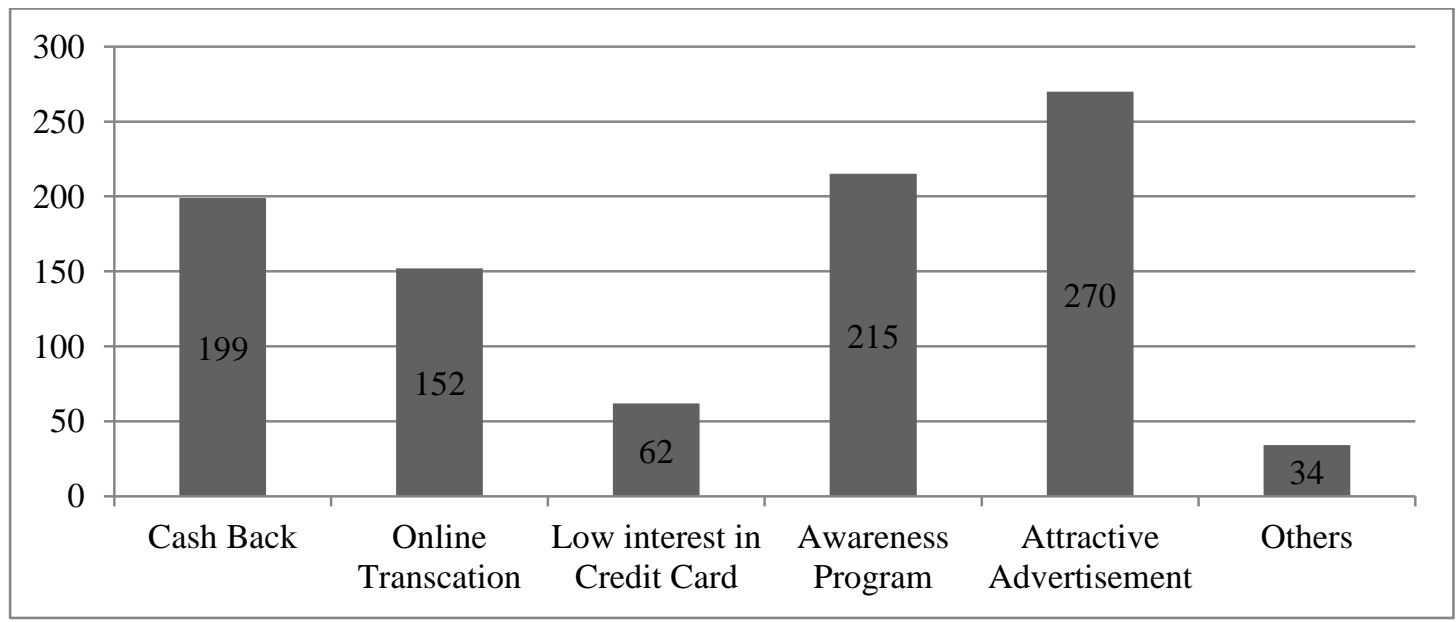

Figure 3. Customer Attraction

If banks provide cashback offers while using the cards, they can attract customers, as revealed by $59.16 \%$ of users. $45.65 \%$ of respondents responded that users would use the card more to do the online transaction without any problems (Figure 3). If the interest rate of 
credit cards is low, then users of credit cards will increase as per $18.62 \%$ of respondents. $64.56 \%$ of respondents said there should be an awareness program about how can use of plastic money help people and make it easier. $81.08 \%$ stated that attractive advertisements could attract plastic money users.

\section{Conclusion}

Based on the finding above, this study concludes that males are prone to use plastic money compared to females in Nepal. This may be because still, the male carries more responsibilities related to transactions, payments than females. Also, traditional payment is still dominant in Nepal though banks and other sectors are offering and accepting cards and POS machines. In addition, it concludes that the most significant challenges in accepting plastic money forget the PIN of the card, card not received on time, theft/loss, fear of hacking and similar others. Respondents feel that cashback offers, low interest in credit cards, attractive advertisements and awareness programs on the use and benefits of using plastic money could attract customers to use plastic money. It is also revealed that the most economically active group (who earns 25001-50000) and those above 21 years to 30 years actively use plastic money. So, this study recommends that attractive advertisements be led by organizations stating they accept plastic money and can access various facilities through plastic money.

\section{References}

Abuarqoub, A. (2019). A lightweight two-factor authentication scheme for mobile cloud computing. In Proceedings of the 3rd International Conference on Future Networks and Distributed Systems, 29, 1-7. https://doi.org/10.1145/3341325.3342020

Adhikari, D. B., Shakya, B., Devkota, N., Karki, D., Bhandari, U., Parajuli, S., \& Paudel, U. R. (2021). Financial Hurdles in Small Business Enterprises in Kathmandu Valley. Modern Economy, 12(6), 1105-1118.

Antony, J. (2018). A Study on the impact of plastic money on consumer spending pattern. Global Journal of Management and Business Research, 18(3), 29-36.

Bansal, M. (2018). An evaluation of consumer perception and attitude towards the usage of plastic money. International Journal of Science Technology and Management, 4(9), 8-52.

Banstola, A. (2007). Prospects and Challenges of E-banking in Nepal. Journal of Nepalese Business Studies, 4(1), 96-104.

Cohen, E. (2009). Growing Information: Part I. Informing science.

Devkota, N., Paudel, U. R., \& Khanal, G. (2021). Is Current Understanding Adequate for Green Banking Practices in Nepal: A Lesson Learned. In Handbook of Research on Climate Change and the Sustainable Financial Sector (pp. 84-98). IGI Global.

Devlin, J. F., Worthington, S., \& Gerrard, P. (2007). An analysis of primary and subsidiary credit card holding and spending. International Journal of Bank Marketing, 25(2), 89-101.

Dhungel, A., Acharya, B., \& Upadhyay-Dhungel, K. (2012). Perception of bank customers about automated teller machine (ATM) service quality. Banking Journal, 2(2), 23-38. 
Eucheuma, A. K. (2004). Savvy atm cardholders' attitude and usage level : a study of Sungai Petani residents (Unpublished Master's Thesis). University of Science, Malaysia.

Fintech Trends. (2018). From Metallic Coins to Online Payments_ A Brief History of Banking in Nepal. https://blog.khalti.com/fintech-trends/brief-history-of-banking-innepal/

Fung, B. and Halaburda, H. (2016). Central Bank Digital Currencies: A Framework for Assessing Why and How. Discussion Papers 16-22, Bank of Canada.

Hernandez, L., Jonker, N., \& Kosse, A. (2017). Cash versus Debit Card: The Role of Budget Control. Journal of Consumer Affairs, 51(1), 91-112.

ICMR (2002). Plastic Money - The Indian Experience_IT and Systems_Case Study_Case Studies. IBS

Center. https://www.icmrindia.org/casestudies/catalogue/IT\%20and\%20Systems/ITSY011.ht $\underline{\mathrm{m}}$

Ismail S., Amin, S., Shayeri, S. F., \& Hashim, N. (2014). Determinants of attitude towards credit card usage. Jurnal Pengurusan, 41, 145-154.http://dx.doi.org/! 0.175 76/pengurusan-2014-41-13

Jain, S. (2016). Customers' Attitude Towards Plastic Money. Management Strategies Journal, 32(2), 79-82.

Khalti. (2018). A Brief History of Banking. Banking. https://blog.khalti.com/fintechtrends/brief-history-of-banking-in-nepal/

Koivunen, T., \& Tuorila, H. (2015). Consumer trust relations with payment cards and banks: an exploratory study. International journal of consumer studies, 39(2), 85-93.

Lanjewar, D. J. (2015). Changing Attitude of Customers Towards Plastic Money. Abhinav Publication, 4(3), 1-4.

Larkotey, W. O., Danso Ansong, E., Damoah, D., \& Laryea, E. A. (2012). Attitude of customers toward the use of ATMs in Sub-Saharan Africa: A Case Study of Ghana. International Research Journal of Computer Science Engineering and Applications, 1(3), 150-158.

Negi, I. (2014). Different Kinds Of Plastic Money. https://www.slideshare.net/indernegi921/plastic-money-33457540

Nepal Rastra Bank. (2019). Banking \& Financial Statistics Nepal Rastra Bank. Banking \& Finacial Statistics, Mid-Dec, 1-61.

Pant, P. R., \& Dongol, D. (2009). Kathmandu Valley Profile: Briefing Paper. Dongol, Devendra. Kathmandu Metropolitan City, Nepal. https://silo.tips/download/kathmandu-valley-profile-briefing-paper

Parajuli, S., Paudel, U. R., \& Devkota, N. (2020). Banking Communications: A Perceptual Study of Customer Relations. South Asian Journal of Social Studies and Economics, 8(3), 23-34.

Paudel, U. R., Parajuli, S., Devkota, N., \& Mahapatra, S. K. (2020). What determines 
customers perception of banking communication? A piece of empirical evidence from commercial banks of Nepal. Global Economy Journal, 20(4), 1-21.

Qureshi, J. A., Baqai, S., Qureshi, M. A., Zulfikar, S., \& Bhutto, A. (2018). Consumers' Attitude towards Usage of Debit and Credit Cards: Evidence from the Digital Economy of Pakistan. International Journal of Economics and Financial Issues, 8(5), 220-228.

Raviprolu, A. (2017). The attitude of the Customers towards Plastic Money. Advances in Economics and Business Management, 4(1), 48-51.

Republica. (2019). NRB lowers card withdrawal limit following ATM heist. MyRepublic. Retrieved from https://myrepublica.nagariknetwork.com/news/useless-homework/

Sharma, A., Karim, S., \& Jain, V. (2015). An evaluation of consumer perception and attitude towards the usage of plastic money in India. International Journal of Science Technology and Management, 4(9), 80-86.

Shrestha, B. \& Tamang, M. (2020). Intention to use ATM cards among students in Kathmandu.

(June

2018). https://www.researchgate.net/publication/342551646_Intention_to_use_ATM_card_a mong_students_in_Kathmandu

Shrestha, S., Devkota, N., Paudel, U., Bhandari, U., \& Parajuli, S.(2020). Bankers' Communication Know-how: An Analysis from Commercial Banks of Kathmandu valley. Quest Journal of Management and Social Sciences, 2(1), 80-99.

Singh, A. S., \& Masuku, M. B. (2014). Sampling techniques \& determination of sample size in applied statistics research: an overview. International Journal of Economics, Commerce and Management, 2(11), 1-22.

Singh, B. (2017). Evaluation of attitude of customers towards plastic money post demonetization. International Journal of Advanced Research and Development, 2(6), 797-799.

Tandukar, H., Devkota, N., Khanal, G., Padda, I. U. H., Paudel, U. R., Bhandari, U., \& Parajuli, S. (2021). An Empirical Study in Nepalese Commercial Bank's Performances on Green Banking: An Analysis From Bankers' Perspective. Quest Journal of Management and Social Sciences, 3(1), 49-62.

Worthington, S. (1996). Smart cards and retailers - who stands to benefit? International Journal of Retail \& Distribution Management, 24(9), 27-34. https://doi.org/10.1108/09590559610130296

\section{Copyrights}

Copyright for this article is retained by the author(s), with first publication rights granted to the journal.

It is an open-access article distributed under the terms and conditions of the Creative Commons Attribution license (http://creativecommons.org/licenses/by/4.0/) 